\title{
PESAN MORAL DALAM CERITA UTTARAKĀNDA RAMĀYĀNA (KAJIAN DALAM PERSPEKTIF SUSILA PENDIDIKAN AGAMA HINDU)
}

\author{
I Dewa Gede Darma Permana \\ Universìtas Hindu Negeri I Gusti Bagus Sugriwa Denpasar \\ email : dewadarma75@gmail.com
}

Diterima: 21 Maret 2021, Direvisi: 10 April 2021, Diterbitkan : 27 April 2021

\begin{abstract}
Itihāsa is one part of the breadth of Vedic knowledge, which must be learned at the initial stage of learning Vedas. Speaking further about Itihāsa, Itihāsa consists of two great epic literature, namely Ramāyāna and Mahäbhārata. So that the initial knowledge that one can learn when studying Itihāsa is the Ramāyāna book. The Ramāyāna book itself is generally composed of 7 parts known as the Sapta Kända. Then in the resolution section there is the final Kända section known as Uttarakānda and of course it contains a moral message. Reflecting on this, this research is interested in examining more deeply the story of Uttarakānda Ramāyana, to find the moral message contained therein in the perspective of Susila's teachings. In this study, several problems were also formulated, namely related to the nature of the Sapta Kānda Ramāyāna, the Uttarakānda Ramāyāna story, and the moral messages contained therein. By using research methods with the type of qualitative research, and literature study and using data analysis from Miles and Huberman. The results of this study indicate that the story of Uttarakānda Ramāyana contains many moral messages that are useful for life. It is hoped that this research can be an initial provision for someone who is just learning the Vedas, then they can become a better person through the moral message they receive.
\end{abstract}

Keywords : Ramāyāna, Moral Message, Uttarakānda

\section{PENDAHULUAN}

Veda merupakan otoritas tertinggi bagi masyarakat Hindu di dalam menjalankan kehidupan sehari-hari. Veda tidaklah hanya sebuah buku yang memberi ajaran berupa sloka-sloka perintah atau dogma semata, melainkan Veda adalah susastra suci yang secara fundamental memberikan pedoman hidup bagi yang mempelajarinya dari sebelum lahir, lahir, bahkan setelah kematian (Sandika, 2014: 1). Pustaka suci Veda bukan hanya terdiri atas satu naskah buku suci yang berisi satu cerita, melainkan terdiri atas banyak pustaka yang memiliki beragam jenis cerita. Beragam jenis cerita tersebut kaya akan kandungan nilai kehidupan yang mampu menuntun umat manusia untuk menjadi pribadi yang lebih mulia.

Bagian dari Veda yang mengandung banyak cerita luhur akan kehidupan bernama Itihāsa. Itihāsa (dalam Sudirga dan Segara, 2014: 50) merupakan kelompok kitab bagian Upaveda yang berbentuk epos, wiracarita atau cerita tentang kepahlawanan. Itihāsa mengacu pada perkembangan sejarah raja-raja yang memimpin pada zaman dahulu. Dengan cerita yang dipercaya berlangsung pada zaman dahulu, ceritanya memang cenderung bersifat fantasi namun khas akan nilai-nilai kewiraan dalam kehidupan. Istilah Itihāsa pada mulanya diberikan oleh penulis kitab Mahābhārata sendiri pada bagian Adi Parwa, yaitu Bhagawan Wyasa. 
Dalam Upaveda, Itihāsa merupakan bagian yang tidak dipisahkan bersama Purana (gambaran historis masa lampau). Dikatakan juga, dengan mempelajari kitab Itihāsa dan Purana, maka seseorang akan lebih mudah mempelajari ajaran Veda. Oleh karena itu dalam hal ini, mempelajari Itihāsa yang berisi cerita luhur akan kehidupan merupakan sesuatu yang sangat penting untuk seseorang dalam rangka mempelajari ajaran Veda yang maha luas, kemudian memahaminya, dan terakhir mengimplementasikannya dalam kehidupan sehari-hari, karena di dalam Itihāsa sendiri terdapat cerita-cerita tentang kedarmawanan, kepahlawanan, pengimplementasian ajaran Veda, dan mengerucut ke ajaran mengenai menjadi manusia yang sebenarnya. Pentingnya mempelajari Itihāsa secara lebih lanjut dapat diketahui melalui Sarasamuccaya sloka 39 yang menyebutkan sebagai berikut:

\section{Itihāsa puranabhyam wedam semupawrmhayet, bibhettyalpacrutadwedo mamayam pracarisyati}

Terjemahan :

"Hendaknya Veda itu dipelajari dengan sempurna, dengan mempelajari Itihāsa dan Purana. Oleh karena Veda itu merasa takut kepada orang yang sedikit pengetahuannya, sabdanya; "duhai tuan-tuan, janganlah mendekati saya" demikianlah sabdanya karena konon merasa takut." (Sudharta, 2019: 21)

Lebih lanjut berbicara mengenai Itihāsa, Itihāsa sendiri terbagi menjadi dua wiracarita yang terbesar dan terkenal di seluruh dunia. Wiracarita tersebut terbagi atas Ramāyāna dan Mahābhārata. Khusus untuk Ramāyāna, wiracarita ini menjadi bagian pertama dalam Itihāsa dengan tokoh terkenalnya yaitu Śrī Rāma dan menjadi bagian pengetahuan Veda yang diturunkan secara turun-temurun untuk membimbing manusia menjadi manusia yang sebenarnya. Untuk itulah, membahas pengetahuan isi kitab Rāmāyana secara lebih dalam dirasa perlu untuk orang awam yang ingin mempelajari ajaran Veda. Namun dalam mempelajari Rāmāyana dengan sungguh-sungguh, sudah barang tentu alangkah baiknya jika seseorang mempelajarinya hingga ke bagian akhir yang disebut dengan Uttarakānda. Terlebih sama seperti bagian resolusi cerita pada umumnya, cerita Uttarakānda sebagai bagian akhir sudah barang tentu memiliki pesan moral yang berguna bagi kehidupan. Dalam tulisan inilah, akan dibahas secara lebih dalam mengenai Uttarakānda sebagai salah satu bagian dari Sapta Kānda Ramāyanna, dan pesan moral yang terdapat dalam ceritanya yang bermanfaat bagi kehidupan saat ini. Akan tetapi mengetahui seluk beluk Sapta Kānda Rāmāyana terlebih dahulu, kemudian mengidentifikasi isi cerita Uttarakānda diperlukan sebagai dasar untuk menggali pesan moral dalam ceritanya bagi kehidupan.

\section{METODE PENELITIAN}

Jenis penelitian yang digunakan dalam penelitian ini adalah jenis penelitian deskriptif dengan pendekatan kualitatif, yang mengkaji tentang kisah wiracarita Rāmāyaņa. Penelitian deskriptif (dalam Salim dan Haidir 2019: 49) adalah penelitian yang mendeskripsikan tentang suatu gejala, peristiwa, dan suatu kejadian. Desain datanya sendiri dalam bentuk teks atau informasi yang didapatkan dalam bentuk teks, disamping menurut Sugiyono (2007: 3) menyatakan bahwa data tersebut dapat diperoleh juga melalui catatan atau berbagai keterangan lainnya sebagai sumber data. Data-data tersebut dalam penelitian ini dikumpulkan dengan metode pengumpulan studi kepustakaan atau literatur yang dalam hal ini mengacu pada beberapa teks atau kepustakaan yang berkaitan dengan kitab Itihāsa terutama yang berkaitan dengan cerita Uttarakānda Ramāyāna.

Setelah literature didapatkan, literature tersebut kemudian dianalisis dengan teknik analisis data Interaktif Miles dan Huberman yang dalam menganalisis data kualitatif terdiri dari tiga 
prosedur kegiatan, yaitu mereduksi data atau memilah data-data yang telah dikumpulkan sesuai dengan topik bahasan, menyajikan data yang telah dipilah terutama yang membantu menjelaskan pesan moral yang terkandung dalam cerita Uttarakānda Ramāyāna, dan pada prosedur terakhir, di tariklah suatu kesimpulan menurut perspektif Susila agama Hindu.

\section{HASIL DAN PEMBAHASAN}

\section{Hakikat Sapta Kända Rämāyanal}

Hakikat Sapta Kānda dalam Rāmāyana adalah menjadi nama struktur atau susunan cerita Ramāyāna yang terbagi atas tujuh bagian. Hal ini bukanlah bualan semata, menurut hasil penelitian dari cerita sejarah, kitab Rāmāyana adalah hasil karya besar dari Mahārși Vālmīki yang menyatakan bahwa, Rāmāyana tersusun atas 24.000 stansa yang dibagi atas 7 bagian yang setiap bagiannya disebut Kānda. Ketujuh dari kānda Rāmāyana itu merupakan suatu cerita yang menarik dan mengasyikkan, karena ceritanya disusun dengan sangat sistematis yang isinya mengandung arti yang sangat dalam. Karena cerita yang dikandung oleh kitab Rāmāyana itu sangat mempesona dengan penuh idealisme pendidikan moral, kewiraan serta disampaikan dalam gaya bahasa yang baik, menyebabkan epos ini sangat digemari di seluruh dunia.

Wiracarita Rāmāyaña sebenarnya terdiri atas beragam gubahan cerita, sehingga isi cerita Rāmāyana seakan ada sedikit perbedaan berdasarkan setiap gubahannya. Namun susunan kitab Rāmāyana tetap berpaku pada susunannya yang terbagi menjadi tujuh bagian yang baku yaitu Sapta Kānda, sehingga esensi ceritanya tetaplah sama. Untuk mengetahui susunan kitab Rāmāyana, disini diperlukanlah untuk menganalisis Sapta Kānda dalam gubahan kitab tertua Rāmāyana yaitu Rämayaņa berbahasa Sanskerta karya Adikavi Välmiki. Nama lain Rāmayana adalah Caturvimsati-sāhasrī-samhita. Hal ini disebabkan oleh karena jumlah śloka (syair) nya sebanyak 24.000 buah. Beberapa pandita Hindu di India percaya bahwa masingmasing keseribu śloka dimulai dengan Gäyatri mantram. Buku Rāmayaņa karya Vālmiki menurut edisi Rämayana oleh Śri Rāmakosa Mandala, Sadāšivapith, Poona, India, terdiri dari 7 kānda, 659 sargah dan 23.864 śloka (Titib, 2008: 14). Ketujuh Kānda tersebut yaitu : Bāla Kānda, Ayodya Kānda, Aranyaka Kānda, Kiskinda Kānda, Sundara Kānda, Yudha Kānda, dan Uttara Kānda (Suratmini dkk., 2016: 18). Kemudian susunan kitab Rāmāyana dengan masingmasing kānda beserta isi singkatnya disebutkan sebagai berikut:

\begin{tabular}{|c|c|c|c|}
\hline No. & Nama Kānda & $\begin{array}{l}\text { Jumlah } \\
\text { Sargah }\end{array}$ & $\begin{array}{l}\text { Jumlah } \\
\text { Sloka }\end{array}$ \\
\hline 1. & $\begin{array}{l}\text { Bālakānda (masa kanak-kanak Šri Rama di Ayodhya } \\
\text { kemudian belajar di Aśrama dan diminta melindungi para } \\
\text { Mahārsi di hutan) }\end{array}$ & 77 & 2.266 \\
\hline 2. & $\begin{array}{l}\text { Ayodhyakānda (penobatan Śrī Rāma sebagai Raja di } \\
\text { Ayodhya yang akhirnya dibatalkan oleh raja Dašaratha, } \\
\text { ayahandanya) }\end{array}$ & 119 & 4.185 \\
\hline 3. & $\begin{array}{l}\text { Äranyakānda (masa pembuangan/ pengembara- an Rāma di } \\
\text { hutan bersama Sita dan Lakşamaņa) }\end{array}$ & 75 & 2.441 \\
\hline 4. & $\begin{array}{l}\text { Kişkindakānda (saat bertemu dengan Hanüman, Sugriva dan } \\
\text { Subali) }\end{array}$ & 67 & 2.453 \\
\hline 5. & Sundarakānda (pembuatan jembatan menuju Lanka) & 68 & 2.807 \\
\hline 6. & $\begin{array}{l}\text { Yuddhakānda (pertempuran Sri Rāma dengan Ravaņa dan } \\
\text { pasukannya) }\end{array}$ & 111 & 5.675 \\
\hline \multirow[t]{4}{*}{7.} & $\begin{array}{l}\text { Uttarakānda (uraian asal dan kembalinya Śrī Rāma sebagai } \\
\text { Avatara Visṇu) }\end{array}$ & 128 & 3.373 \\
\hline & Jumlah & 645 & 23.200 \\
\hline & Praksipta (tambahan) & 14 & 664 \\
\hline & Jumlah keseluruhan & 659 & 23.864 \\
\hline
\end{tabular}


Dengan mengetahui tabel tersebut, dapat diketahui bahwa masing-masing Kānda memiliki cerita-cerita tersendiri secara bertahap, dan yang membedakannya dengan bagian Kānda yang lain.

\section{Cerita Uttarakānda sebagai Bagian Resolusi dalam Sapta Kānda Ramāyāna}

Sebagai salah satu bagian Sapta Kānda dari kitab Rāmāyana dengan puluhan ribu slokanya, Uttarakānda akan ditemui oleh pembaca pada saat menuju atau berada di bagian akhir cerita Rāmāyana. Perlu diketahui Uttarakānda sebagai bagian akhir dari cerita Rāmāyana, berisi resolusi atau tahap penyelesaian dari konflik berkepanjangan yang terdapat dalam cerita. Kemudian juga menjadi tahap Koda yaitu tahap akhir yang berisi pembelajaran atau makna yang terkandung dalam wiracarita Ramāyāna.

\subsection{Cerita Inti Uttarakānda}

Secara garis besar, ikhtisar ringkas dari cerita inti bagian Uttarakānda Rāmāyana dapat diketahui sebagai berikut (diringkas dari Sudirga dan Segara, 2014: 35-36 dan Titib, 2008: 6773):

Uttarakānda adalah kānda yang ke-7 dalam wiracarita Rämäyaṇa (terakhir) yang secara pokok menceritakan asal-usul kelahiran putra kembår Śrī Rāma yakni Kuśa dan lava. Bagian ini terdiri dari 111 sargah dan dimulai ketika Śri Rama berhasil membunuh Prabhu Rävaņa dalam sebuah perang besar untuk merebut kembali Dewi Sitā. Setelah memenangkan pertempuran, beliau kembali menjadi raja di kota yodhya diiringi oleh istrinya Dewi Sītā dan saudaranya Lakşamana. Šri Rāma kemudian memerintah Kerajaan Kauśalyä bersama istrinya Dewi Sita yang menjadi seorang ratu. Mereka hidup berbahagia dengan segala persoalan pemerintahan yang dihadapi senantiasa menyenangkan dan membahagiakan mereka.

Tidak beberapa lama Dewi Sita hamil. Śrī Rāma sangat senang karena akan lahir putra beliau untuk melanjutkan keturunan dan tahtanya. Śrī Rāma kemudian berjanji akan mengabulkan segala permohonan Dewi Sita. Dewi Sita kemudian tidak menuntut lebih, beliau hanya mengharapkan agar suaminya senantiasa bahagia, dan ingin sekali memberikan sedikit persembahan kepada istri para pertapa (Brahmana) di hutan sebagai rasa syukur. Śri Rāma sangat gembira kemudian menyetujui dan memenuhi keinginan Dewi Sitā. Setelah beberapa hari berlalu, pada suatu pagi Śrī Rāma duduk di balairung, melaksanakan tugas-tugasnya sebagai seorang raja. Pada saat itu seorang bagawan datang menghadap. Ia telah dapat melaksanakan tugas-tugasnya, menyamar untuk mendengarkan pembicaraan orang-orang yang berbeda-beda di dalam masyarakat. Pada pagi harinya ia menghadap raja, bahwa semalam ia telah mendengarkan orang-orang yang membicarakan dan mengeritik sang raja. Itulah yang dilaporkan kepada Śrī Rāma, apa yang telah dilihat dan didengarnya langsung. Ia berkata bahwa di penduduk kerajaan banyak yang mempertanyakan ketidaksucian Dewi Sita. Hal tersebut karena Dewi Sita diculik oleh Ravana sebagai raksasa yang durjana selama beberapa waktu.

Mendengar hal tersebut Śri Rāma sangat tertusuk dan pedih hatinya. Beliaupun mengetahui bahwa Dewi Sita adalah orang yang selalu memikirkan dirinya dan suci. Namun demikian seorang raja hendaknya selalu memperhatikan perbuatan-perbuatan yang dapat menggembirakan dan bertujuan untuk kesejahteraan masyarakat, oleh karena itu beliau memutuskan untuk mengusir Dewi Sita. Beliau memanggil saudaranya Lakşamaņa dan menceritakan kepadanya hal-hal yang telah didengarkan lewat punggawanya. Beliau memerintahkan Lakşamana untuk membawa Dewi Sita dan meninggalkannya di tengah-tengah hutan dekat pertapaan Mahärşi Valmiki. Lakşamaņa terkejut dan tercengang atas perintah yang diberikan oleh Sri Rama, namun Laksamana tidak dapal menentukan pilihan lain, kecuali membawa Dewi Sitā ke luar istana. Lakşamaņa membawa sebuah kereta ke luar dari gerbang 
keputre tempat Dewi Sītä. Dewi Sita memikirkan bahwa Śri Râma telah memenu keinginannya untuk mengunjungi istri-istri pertapa ditengah hutan. Beliau sangat bergembita. Dewi Sita cukup banyak membawa oleh-oleh, seperti gelang-gelan dan ukiran emas, talam dan perlengkapan pemujaan untuk disampaikan kepada para istri pertapa. Beliau mengatakan kepada setiap orang di keputren bahwa beliau segera berangkat mengunjungi pertapaan. Pada saat itu kebetulan Srī Rāma tidak ada di istana. Kemudian Dewi Sītā minta izin kepada ibu mertuanya dewi Kosalya, dan diminta pula kepada beliau untuk menyampaikan kepada Srī Rāma tentang perjalanannya itu. Lakşamaņa sendiri yang mengemudikan kereta yang dipergunakan oleh Dewi Sītā: Perjalanan mereka sangat cepat dan segera pula sampai ditepi Sungai Gangāa, dekat dengan pertapaan Mahārşi Vālmiki. Tetapi Lakşamaņa tidak langsung pergi kepertapaan. Beliau pergi membawa Dewi Sìtā ke tengah hutan dan segera menurunkannya dari kereta. Dengan air mata berlinang-linang Lakşamaņa berkata kepada Dewi Sītā menjelaskan maksud beliau membawa Dewi Sita ke dalam hutan, dan meminta maaf atas perbuatannya karena ini adalah perintah dari seorang raja kepadanya. Dia tidak dapat berbuat banyak selain menuruti perintah kakaknya. Kemudian Lakşamaņa bersujud di hadapan Dewi Sitā dan mohon diri untuk siap berangkat kembali ke Ayodhyāpura. Kata-kata Lakşamaņa bagaikan halilintar yang menyambar Dewi Sītā. Beliau berdiri sejenak sambil mengikuti perjalanan Lakşamaņa lewat pandangan matanya. Sangat jauh pandangannya dan hatinyapun sangat sedih tiada taranya, sehingga beliau jatuh pingsan dan berguling merangkul tanah. Setelah siuman beliau mengingat kembali kisah dan kenangan hidupnya.

Dewi Sita tidak dapat memakan apa-apa, pikirannya penuh dengan kesedihan, wajahnya sangat kusut. Beliau tidur dan terlentang di bawah naungan sebuah pohon. Setelah petang hari, Dewi Sitā bangun dari tidurnya. Beliau tidak mengetahui apa yang harus dikerjakan dan tidak tertahankan akhirnya menjerit dan menangis sekeras-kerasnya. Saat itu para siswa Mahārşi Vālmīki pergi ke tengah hutan untuk mengumpulkan kembang-kembang dan dedaunan yang akan dipergunakan sebagai alat pemujaan petang hari. Mereka mendengar rintihan keras dari Dewi Sitā. Mereka mendekati Dewi Sītā, memperkenalkan diri dan mengajak Dewi Sita untuk pergi ke pertapaan Mahārşi Vālmīki. Dengan ketabahan hatinya Dewi Sita pergi menuju pertapaan Mahārşi Vālmīki, diikuti oleh para siswa yang menunjukkan sikap sopan kepadanya. Segera beliau melihat Maharşi Valmīki, Dewi Sita pun langsung bersimpuh di hadapannya. Dewi Sitā sangat tertekan dan menderita, Mahärși Valmiki menyambut dengan keramahan, kesejukkan hati dan kata-kata manis yang menentramkan hati Dewi Sitā. Kemudian dengan air mata berlinang Dewi Sita menceritakan seluruh kisahnya kepada Mahārşi Välmīki. Hati Mahārși sangat iba mendengar cerita Dewi Sitā. Beliau memberikan nasehat dan petunjukpetunjuk hidup lainnya. Beliau menjamin Dewi Sitā untuk tinggal bersama di pertapaannya. Beliau memberitahu para ibu di pertapaan bahwa Dewi Sitā adalah seorang yang dirakhmati Tuhan Yang Maha Esa, mereka diharapkan menjaganya bersama serta memberikan kasih sayang kepadanya.

Setelah beberapa lama Dewi Sītā tinggal di pertapaan Mahārşi Vālmiki, beliau melahirkan putra kembar. Mereka lahir pada hari yang baik di bawah naungan bintang yang cemerlang. Kedua bayi itu sangat tampan, seakan-akan boneka yang dibuat dari emas yang disinari bulan purnama. Setelah sepuluh hari dari kelahirannya kedua bayi itu diberi nama Kuśa dan Lava. Setiap orang dipertapaan sangat mencintai bayi-bayi itu, mereka menimang-nimang dan memanjakannya. Mereka memberikan kasih sayangnya kepada putra-putra kembar Dewi Sitä dan menghibur hati Dewi Sītä setiap saat. Melihat putra- putranya yang rupawan itu, Dewi Sìtā dapat melepaskan kesedihannya. Hal ini memberikan pula kebahagiaan yang tidak terhingga kepada Mahārşi Vālmīki.

Kuśa dan Lava dari hari ke hari bertambah dewasa. Mahärsi Valmiki mengajarkan kepada mereka pelajaran dasar, membaca dan menulis. Anak- anak itu diajarkan untuk merapalkan mantra-mantra pemujaan serta lagu lagu keagamaan. Suara anak-anak itu sangat merdu dan 
membuat pendengarnya menjadi sangat terpesona. Mahārşi Vālmiki sering meminta kedua anak itu untuk menyanyi di hadapan ibunya Dewi Sita. Nyanyiannya sangat mengasyikkan, bagaikan tīrtha amrta. Kuśa dan Lava kini telah berumur 8 tahun. Pada masa ini Mahārsi Vālmik melaksanakan upacara suci "upānayana" kepada Kuśa dan Lava. Sejak sa itu pula beliau diajarkan pula menyanyikan wirama dalam Rämayaņa. Kadu anak itu belajar dengan sungguh-sungguh. Lagu-lagu šloka Ramāyāna sang menyenangkan hatinya dan Maharşi Valmiki sangat gembira memperhatikan hal tersebut. Mereka menyanyikan śloka-śloka Rāmāyaņa dihadapan ibunya Dewi Sītā. Hati ibunya hancur luluh mendengar kisah Rāmäyaņa yang dinyanyikan oleh kedua putranya. Lagu-lagu Rāmāyaņa memberi keindahan dan kerinduan hati bagi Dewi Sītā. Air matanya mengalir penuh keharuan. Mahārși Välmīki kagum dan bangga oleh kedua anak yang sedang asyik menyanyikan kisah Rāmäyaņa itu. Beliaupun menyuruh Kuśa dan Lava menyanyikan śloka-śloka Rāmäyaṇa itu di hadapan setiap orang yang datang ke pertapaan Maharși.

Seiring berjalannya waktu, kedua putra kembar itu segera meningkat dewasa. Dari hari ke hari menunjukkan kemajuan terutama dalam pendidikan yang diselenggarakan di pertapaan Mahārși Vālmīki. Selama itu pula pemerintahan Śri Rāma di Ayodhyāpura terus berlangsung, Namun kenangan dan kecintaannya kepada Dewi Sitā tidak pernah padam. Beliau merencanakan untuk menyelenggarakan upacara besar "Aśvamedhayajña". Pada waktu itu upacara Aśvamedhayajña sangat besar artinya. Upacara besar itu dimaksudkan untuk menunjukkan keagungan seorang raja. Hanya raja-rajalah yang akan berhasil melaksanakan upacara tersebut. Seorang raja yang ingin menyelenggarakan upacara tersebut, haruslah memilih seekor kuda dari ras yang terbaik. Kuda tersebut dilepas oleh sang raja untuk menjelajah wilayah kerajaan lain. Ada raja yang berani menangkap kuda tersebut dan menaklukkan pengikutnya di dalam suatu peperangan maka upacara besar tersebut berarti gagal. Jelasnya bagi seorang raja yang ingin melaksanakan upacara Aśvamedhayajña, haruslah dapat menundukkan semua raja di atas dunia ini dan raja itu akan menjadi "mahārājādirāja". Setelah kuda berhasil menjelajahi seluruh negara dan kembali pulang dalam keadaan selamat, maka yang dimiliki kuda tersebut baru akan berhasil melaksanakan upacara tersebut yang penuh resiko itu. Seluruh raja-raja di atas bumi ini menghaturkan hadiah dan upeti mercka. Pada waktu upacara besar itu berlangsung semua rși di wilayah kerajaan diundang ke Ayodhyapura untuk menghadiri upacara tersebut. Demikian pula Mahārși Vālmīki dengan dua orang siswanya ikut hadir menyaksikan upacara di pusat kota Ayodhyāpura.

Upacara besar Aśvamedhayajña yang diselenggarakan oleh Śri Rāma berlangsung beberapa hari dengan sangat megahnya. Orang-orang miskin bergembira karena diberikan makanan dan pakaian secukupnya. Para Brähmaņa dan rsi sangat senang hatinya menerima hadiah dan uang. Ketika hari terakhir seluruh rși dikumpulkan bersama-sama. Pada petangnya di hadapan para rsi, Maharşi Välmiki menyuruh Kuśa dan Lava untuk merapalkan śloka dari Rāmāyaņa hasil karyanya. Siswa yang lainnya memainkan seruling sangat menyenangkan. Pada hari itu malam bulan purnama raya. Seruling berlangsung berlangsung semalam suntuk. Para rsi dan Brahmana yang hadir semuanya sangat berkesan. rara rsi dan Brahmana, sangat puas mendengarkan dan memberi hadiah kepada putra kembar tesebut. Maharsi Valmiki sangat gembira atas penghargaan yang diberikan karena keindahan syairnya yang dibacakan oleh siswanya. Ketika berlangsungnya pembacaan sloka-śloka Rämäyaņa semalam Suntuk, Śrī Rāma mendengarkannya sambil berbaring pada teras di depan istananya. Beliau mendengar nyanyian yang diucapkan oleh dua orang anak laki. Hal tersebut seakan-akan amrta bagi beliau.

Sri Rāma kemudian meminta kedua anak itu untuk tinggal beberapa hari. Pada pagi harinya ketika beliau datang ketempat pertemuan itu, beliau meminta mereka untuk mengulangi pembacaa Ramayaņa sekali lagi. Beliau mendengarkan nyanyian tentang kisah hidupnya Śrī Rāma berlinang-linang air matanya ketika disebutkan nama Dewi Sita dalam kisah tersebut. Kemudian dengan perasaan yang campur aduk, beliau kemudian bertanya mengenai asal-usul 
kedua anak tersebut. Anak tersebut kemudian memperkenalkan diri sebagai Kusa dan Lava, putra dari Dewi Sita, dan siswa dari Mahārși Vālmīki. Mendengar hal tersebut, Sri Rāma kemudian terkejut, dan sangat gembira bahwa dia memiliki dua orang putra yang hebat. Segera beliau memanggil Mahārși Vālmīki pada suatu hari. Ketika Mahārși datang, Śrī Rāma mendengarkan dari beliau cerita tentang kedua dari anak itu secara mendetail. Beliau segera meminta agar Dewi Sitā dikembalikan. Beliau memberi jaminan bahwa Dewi Sìtā segera diangkat menjadi ratu kembali di Kerajaan Kośala.

Dengan rasa hormat dan bahagia mahārşi Vālmīki memerintahkan siswanya untuk menghantarkan Dewi Sitä dari pertapaannya ke istana. Ketika Dewi Sītā tiba di istana, Śrī Rāma dengan maksud meyakinkan kesucian Dewi Sita kepada rakyatnya kemudian berkata: " Istriku Sitā, bersumpahlah engkau di hadapan para Mahärși di sini, bahwa engkau mencintai aku sendiri dan engkau adalah seorang yang benar, seorang wanita yang dirakhmati Tuhan. Lenyapkanlah keragu-raguan pikiran mereka yang hadir pada pertemuan ini oleh penjelasanmu. Kemudian barulah aku mengambilmu kembali!"

Namun dengan rasa kecewa, mahārși Vālmiki memprotes, beliau berkata kepada Śrī Rāma bahwa kesucian Dewi Sita lewat dua orang putranya tidak dapat diragukan dan diuji lagi. Akan tetapi, menjalankan kewajibannya sebagai seorang raja Šrī Rāma tidak menyetujuinya. Beliau bersabda bahwa pengujian atas kesuciannya mesti dilakukan untuk melenyapkan kecurigaan masyarakat Dewi Sitā. Dengan rasa sedih Dewi Sita kemudian berdiri dengan menengadakan kepalanya. Air mata mengalir seperti aliran sungai meleleh dari kelopak matanya Para Devatā turun dari kahyangan untuk meyakinkan ujian kesucian seorang wanita. Di depan para Devatā, dan para rși. Dewi Sita memuja Dewi Prthivi \}

"Om ibu Prthivi, bilamana semuanya benar bahwa saya tidak pernah memikirkan orang lain kecuali Śrī Rāma, sambutlah saya dengan tanganmu bunda. Om ibu Prthivi, jika hamba masih suci, dan semua hal itu benar bahwa saya hanya memuja Śri Rāma, segera sambutlah saya. Apa kata-kata hamba semuanya benar, Om ibu Prthivi, ambillah hamba dengan tanganMu bunda".

Seperti yang diucapkan Dewi Sitā, tiba-tiba tanah pun meledak dan terbuka. Dari sana kemudian muncul sebuah singasana mawar muncul di hadapannya. Bhūdewi atau nama lain dari ibu Prthivī duduk di atas singasana yang didukung oleh empat ekor ular naga. Dewi Prthivī mengambil Dewi Sītā dan merangkulnya. Dalam sekejap mata, keduanya lenyap masuk ke dalam bumi bersama singasana, kemudian tanah yang tadinya terbuka kini tertutup kembali. Melihat Dewi Sitā lenyap masuk ke dalam bumi, Śrī Rāma sangat sedih hatinya. Beliau menangis menjerit-jerit. Dewi Sitā adalah putri dari Dewi Prthivi. Beliau kembali ke dalam pangkuannya. Śn̄ Rāma memuja Dewi Prthivī, mertuanya untuk memohon supaya istrinya kembali lagi kepadanya, beliau memarahi dirinya sendiri, sangat mengharapkan kembalinya Dewi Sītā, tetapi itu semuanya sia-sia. Kemudian muncul Hyang Brahmā, Tuhan Yang Maha Esa sebagai pencipta alam semesta dan bersabda dengan kerasnya : "Śr̄̄ Rāma, ingatlah! Anda bukanlah makhluk biasa, melainkan adalah Nārāyaṇa sendiri. Engkau diturunkan sebagai manusia hanyalah untuk membunuh Raja Rākşasa Rāvaņa. Dan sekarang, tujuan anda lahir kedunia telah berhasil dilaksanakan, engkau mestinya segera kembali ke kahyanganmu yatu Vaikuntha. Śakti-Mu Dewi Sìtā telah menunggumu di sana sebagai Dewi Lakşmi". Śrī Rāma kemudian tersenyum dan sadar bahwa kata-kata itu benar, penderitaannyapun segera lenyap. Musyawarah para Devatā dan orang-orang suci membenarkan dan takjub menyaksikan kejadian itu. Beberapa hari setelah peristiwa itu, akhirnya Śri Rāma kembali ke Vaikunthaloka dan tinggal bahagia bersama istri-Nya Sita dalam wujud Dewi Laksmi.

\subsection{Cerita Sisipan Uttarakānda}

Selain menceritakan tentang pengasingan Dewi Sita, bagian akhir Uttarakānda juga menceritakan beberapa cerita sisipan. Salah satunya ialah mengenai asal-usul para raksasa. 
Cerita tersebut (dalam Titib, 2008: 134-136) dipaparkan secara singkat dan pada sebagai berikut:

Para rși agung bertemu Śrī Rāma di balai sidang yang agung percakapannya dengan mereka dan pertanyaan-pertanyaannya yang ditujukan kepada mereka. Di dalam siding terdapat wejangan dari bhagavān Agastya tentang manfaat pertapaan yang dilakukan oleh Pulasatya dan asal-usul Viśravā. Dijelaskan pula kelahiran Vaiśravaņa dari daging pinggang Viśravā sehingga diperolehnya anugerah melalui tapa dan kediamannya di Lankā. Suatu pemaparan tentang ras rākşasa and asal-usul Heti, Vidyutkeśa dan Sukeśa. Uraian tentang keturunan Mālyavān, Sumālī dan Mālī, putra-putra Sukeśa yang atas nasihat Dewa Šiva, para Dewa mencari bantuan Śrī Visnu untuk penghancuran para rākşasa; mereka kembali diyakinkan; kaum Rākşasa merebut wilayah para Dewa; kedatangan Srī Vișnu membantu para Dewa Kehancuran kaum rākşasa oleh Dewa Vișņu, rākşasa yang masih hidup melarikan diri. Pertarungan Malyavān dan kekalahannya, mundurnya Sumālī dan rāksasa lainnya ke lapisan dunia yang lebih rendah.

Asal-usul Rāvaņa dan yang lainnya, kediaman mereka di Gokarna untuk melakukan Tapa. Rāvaņa dan adik-adiknya melakukan tapa (meditasi) dan memperoleh anugerah. Diceritakan pula terkait Dewa Kubera (Kekayaan) mendengar ultimatum Rāvaņa untuk meninggalkan Lańkā dan Rāvaņa yang dinobatkan menjadi raja. Perkawinan Šūrpaņakhā, perkawinan Rävaņa dan saudaranya dan kelahiran Meghanāda. Kumbhakarņa tidur di rumah yang dibangun atas perintah Rāvaņa; pelanggaran Rävaņa; Kubera mengirim utusan untuk menghentikannya; utusan itu dibunuh oleh Rāvaña yang berang. Sebuah serangan oleh Rāvaṇa dan para menterinya terhadap kaum Yakşa dan kaum Yakşa menderita kekalahan. Kekalahan Manibhadra dan Kubera; Rāvaṇa mengambil alih kepemilikan kereta angkasa Puspaka. Nandiśvara mengutuk Rāvaņa; Dewa Śamkara mengekang kebanggaan Rāvaņa, yang memperoleh anugrah pedang dari Dewa Śamkara.

Diceritakan juga terkait Vedavatī, putri seorang Brahmarşi yang dihina dan hampir dilecehkan oleh Rāvaņa, putri itu mengutuknya dan memasuki api. Ia terlahir sebagai Sītā pada kelahiran berikutnya. Tindakan memalukan Marutta kepada Rāvana; Dewa Indra dan dewadewa lainnya memberi anugerah kepada burung merak dan burung lainnya. Rāvaņa membunuh Anaranya dan menerima kutukan darinya. Ravaņa dihentikan oleh Nārada; atas sarannya ia merebut tempat tinggal Yama. Rāvaña kemudian menduduki tempat tinggal Yama dan menghancurkan kekuatan Yama. Pertarungan antara Yama dan Rävaņa; Yama ragu-ragu, atas campur tangan Dewa Brahmā, senjata penghancurnya yang diangkat untuk menghabisi Rāvaņa; setelah memenangkan pertarungan Rāvaņa meninggalkan tempat tinggal Yama. Ravaņa bersahabat dengan kaum Nivātakavacha, membunuh Kālakeya dan mengalahkan dengan mulus putra Varuņa. Membayangkan bidadari dan gadis lain yang diculik oleh Rāvaņa dan kutukan yang mereka ucapkan; Rāvaņa menghibur adiknya yang dilanda kesedihan, Sūrpaņakhā, dan mengirimnya ke hutan Dandaka bersama Khara. Meghanāda meraih keberhasilan melalui upacara korban; Vibhisşana menggambarkan dampak yang buruk melarikan istri-istri orang; setelah menghibur Kumbhinasī, Rāvaņa, ditemani oleh Madhu, menduduki kahyangan para Dewa Rävana memperkosa bidadari Rambhä dan menerima kutukan yang mengerikan dari Nalakūbera. Rävaņa, bersama pasukannya, menduduki kahyangan Dewa Indra; Dewa Indra memohon bantuan Dewa Visnu; Dewa Visnu kemudian berjanji akan membebaskan Dewa Indra.

Cerita tambahan juga menceritakan kisah Śrī Rāma yang bertindak adil kepada anjing yang masuk ke istananya, dan menguji Brāhmana 'Kulapati' (seorang Mahänta) dari Kalañjar. Anjing itu menunjukkan kejahatan yang berhubungan dengan tawaran Kulapati. Cerita para bhagavän yang tinggal di tepian Yamunā, diteror oleh Asura Lavana. Mereka kemudian mendekati Śri Rāma agar mengajukan keberatan. Srī Rāma menerima mereka dengan hormat dan menanyakan maksud kedatangan mereka. Para mahārși memberitahu Śrī Rāma tentang 
anugerah yang diperoleh Asura lavana dan kekuatannya, dan kekejaman dilakukan dan menarik Śri Rāma untuk menghilangkan ketakutan mereka. Rāma menanyai para bhagavān sehubungan dengan perilaku Lavaņa dan mengirim Šatrughna dengan maksud membunuh Lavaņa. Šatrughna mengirim pasukannya memenuhi permintaan Śri Rāma lebih awal dan ia sendiri menyusul sebulan kemudian. Lebih lanjut Bhagavān Cyavana kemudian memberitahu Śatrughna akan kekuatan tombak Lavaņa dan menceritakan kejadian-kejadian yang berhubungan dengan pembunuhan Raja Māndhātā. Lavaņa pergi mencari makan. Šatrughna berjaga-jaga di gerbang kerajaan menunggu kembalinya Lavaņa dan terjadi percekcokan di

antara mereka. Perkelahian pun meletus antara Śatrughna dan Lavaņa dan didalam pertempuran tersebut Šatrughna berhasil menghabisi Lavana.

\section{Pesan Moral dalam Cerita Uttarakānda bagi Kehidupan}

Dalam Kamus Bahasa Indonesia 'pesan' diartikan sebagai perintah, nasihat, permintaan, amanat, dan segala sesuatu yang hendak disampaikan lewat orang lain. Sementara kata 'moral' sendiri berasal bahasa Latin yaitu "mores" yang diartikan sebagai tata-cara dalam kehidupan, adat-istiadat, kebiasaan, kemudian beralih kata menjadi moralitas. Moralitas sendiri berarti tingkah laku yang dianggap mulia dan sesuai dengan nilai-nilai tata cara/adat yang ada dalam sesuatu kelompok yang disusun dalam suatu aturan disebut norma (Gunarsa, 2017: 38). Dalam hal ini, moral sudah masuk dalam tahap praktik di kehidupan, dan tercermin secara langsung melalui tingkah laku dalam masyarakat. Jadi dari penjelasan kedua kata tersebut dapat diketahui bahwa pesan moral adalah sebuah nasihat atau amanat yang berkaitan tentang bagaimana cara untuk hidup atau bertingkah laku mulia sesuai aturan norma yang berlaku. Sehingga pesan moral sangat diperlukan demi membimbing manusia berperilaku yang semestinya dalam kehidupan. Ketika sudah mengetahui definisi dan pentingnya pesan moral tersebut, tentu pesan moral tersebut perlu juga digali dalam cerita Uttarakānda.

Dalam agama Hindu sendiri, salah satu dari tiga kerangkanya yaitu Susila, memberikan pengetahuan yang secara khusus mengenai tingkah laku bermoral. Kata Susila secara etimologi berasal bahasa Sanskerta yaitu kata 'su' yang berarti baik atau mulia, sementara kata 'sila' mengacu pada definisi tingkah laku, praktek, watak, atau kelakukan. Jadi dalam hal ini, Susila memiliki arti sebagai segala tindakan, tingkah laku, praktek, atau kelakuan yang mulia, baik, sopan, dan sesuai dengan ketentuan-ketentuan Dharma (kebenaran) dan Yajna (pemberian yang tulus berdasarkan cinta kasih) (Oka, 2009: 43). Susila kemudian berkembang dan lebih dikenal secara lebih lengkap menjadi suatu aturan yang disebut dengan tata susila. Prof. Dr. Ida Bagus Mantra (2018: 1) mendefinisikan tata susila sebagai peraturan tingkah laku yang baik dan mulia, sehingga dalam hal ini mesti dijadikan pedoman hidup oleh manusia. Sehingga dalam mengidentifikasi pesan moral dalam cerita Uttarakānda, diperlukan juga ajaran Susila sebagai acuannya. Setelah proses mengidentifikasi tersebut selesai, ditemukan beberapa pesan moral dalam cerita Uttarakānda yang dipaparkan sebagai berikut:

\subsection{Kesetiaan Istri dan Suami dalam Grehastha Asrama}

Grehastha Asrama adalah masa kehidupan disaat menjalani ikatan Suami dan Istri. Dalam masa ini, Artha (kekayaan) dan Kama (Kenikmatan) menjadi tujuan hidup namun dengan tetap berlandaskan Dharma atau kebenaran (Adiputra, 2004: 122). Dalam jenjang kehidupan ini, ada jenis masa lagi yang disebut dengan Sewala Brahmacari (dalam Sudirga dan Segara, 2014: 153), Sewala Brahmacari adalah kehidupan suami-istri yang hanya kawin sekali seumur hidupnya, meskipun salah satu dari pasangannya meninggalkannya. Dalam cerita Uttarakānda, hal ini ditunjukkan oleh Śrī Rāma dan Dewi Sita, dimana walau banyak halangan dan rintangan yang menerjang kehidupan pernikahan mereka, tidak ada salah satu dari mereka yang berhianat atau menikah lagi. Bahkan disaat Dewi Sita dengan terpaksa diasingkan karena tekanan masyarakat Ayodhya, keduanya masih setia dan saling memikirkan satu dengan yang lainnya sebagai pasangan suami dan istri. Bahkan Śrī Rāma sendiri masih percaya akan kesucian istrinya, meskipun banyak isu miring mengenai hal tersebut. Pengajaran ini menjadi sebuah 
pesan moral yang bisa diimplementasikan dalam kehidupan berkeluarga di era sekarang. Dimana, kasus kawin cerai menjadi hal yang lumrah, atau pasangan suami istri yang tidak setia. Padahal dalam ajaran agama Hindu sendiri, pasangan suami istri yang setia menikah atau kawin hanya sekali dalam seumur hidupnya sangat ditekankan. Hal ini diungkapkan dalam kitab Manawa Dharmasastra IX. 101 sebagai berikut:

\section{Anyonyasyawyavy abhicaro bhaved amaranantikah, esa dharmah samasena jneyah stri pumsayoh parah.}

Terjemahannya:

"Hendaknya supaya hubungan yang setia berlangsung sampai mati" singkatnya, ia harus dianggap sebagai hukum yang tertinggi bagi suami dan istri." (Gata dkk., 2020: 39).

Bahkan perceraian juga dilarang dalam Manawa Dharmasastra IX. 102, lewat slokanya sebagai berikut:

\section{Tatha nityam yateyatam stripumsan tu kritakriyan, yatha nabhicaretam tan wiyuktamtaretaram}

Terjemahannya:

"Hendaknya laki-laki dan perempuan terikat dalam ikatan perkawinan, mengusahakan dengan tidak jemu-jemunya supaya mereka tidak bercerai dan jangan hendak melanggar kesetiaan antara satu dengan yang lain." (Gata dkk., 2020: 39).

Jadi sangat pentinglah bagian Uttarakānda sebagai pesan moral untuk pasangan suamiistri dalam menjalani bahtera rumah tangga agar setia dan saling mempercayai satu dengan yang lainnya.

\subsection{Penghormatan kepada Wanita}

Penghormatan kepada wanita terlebih lagi untuk seorang Ibu, di dalam kehidupan merupakan perbuatan yang mulia. Bahkan dalam Manawa Dharmasastra III. 56 mempertegas hal tersebut. Bunyi slokanya sebagai berikut:

\section{Yatra naryastu pujyante ramante tatra dewatah, yatraitastu na pujyante sarwastlah ksiyah.}

Terjemahannya:

"Dimana wanita dihormati, disana para Dewa-dewa merasa senang, tetapi dimana mereka tidak dihormati, tidak ada upacara suci apapun yang akan berpahala." (Buditha, 2019: 108).

Hal inilah yang diajarkan oleh mahārşi Vālmīki dan para muridnya di pertapaan. Di dalam cerita Uttarakānda, dengan tidak peduli terhadap asal-usul Dewi Sita, dengan penuh kasing sayang dan lemah lembut, para murid beserta mahārşi Vālmīki menyambut dan merawat Dewi Sita sebagai seorang wanita yang diasingkan. Bahkan dengan penuh rasa hormat, sampai Dewi Sita melahirkan dua orang putra bernama Kusa dan Lava, mahārşi Vālmīki masih setia merawat dan memperjuangkan kesucian Dewi Sita kepada Śrī Rāma. Bahkan putra Dewi Sita menjadi dua orang anak yang berbhakti di bawah bimbingan mahārşi Vālmīki. Cerita ini juga seakan mengisyaratkan bahwa agama Hindu adalah agama yang menempatkan wanita dalam posisi yang terhormat dan mulia. Bahkan 
penghormatan ini dipertegas lagi dalam Yajur Veda XIV. 21 (dalam Buditha, 2019: 109), sebagai berikut:

"Oh ibu, engkau adalah perintis kecemerlangan, pendukung yang memberi kami makan

dan menjalankan aturan layaknya bumi.

Kami memiliki engkau di keluarga, sebagai berkah untuk menikmati usia panjang, kecemerlangan, kemakmuran, dan kesuburan dalam kehidupan.”

Pembelajaran untuk menghormati seorang wanita terlebih seorang ibu dalam cerita Uttarakānda ini, bisa dipelajari, dihayati, dan diimplementasikan sebagai tameng untuk meminimalisir kasus-kasus pelecehan, diskriminasi, dan kekerasan fisik terhadap perempuan di era saat ini. Jangan sampai seperti asal-usul Rahvana yang terdapat dalam cerita Uttarakānda. Rahvana mengalami kutukan dan kehancuran karena pernah menghina dan hampir melecehkan Vedavatī, putri seorang Brahmarşi. Perbuatan tercela ini sebenarnya sudah diingatkan akan membawa mala petaka dalam kitab Manawa Dharmasastra III. 58 (dalam Buditha, 2019: 109), yang lebih jelasnya berbunyi sebagai berikut:

\section{Jamaya yani gehani. capantya patri pujitah tani krtyahataneva, winacyanti samantarah.}

Terjemahannya:

"Dimana ada sebuah rumah, yang tidak menghormati wanita sebagai mana mestinya, bahkan sampai terucap kalimat kutukan, keluarga itu akan mengalami kehancuran sepenuhnya seperti dibinasakan oleh kekuatan yang tidak wajar (gaib)."

\subsection{Berkorban demi Kepentingan Umum dibandingkan Kepentingan Pribadi}

Seorang pemimpin memang sudah selayaknya berkorban demi kepentingan umum. Bahkan rela mengesampingkan kenikmatan pribadinya. Pengorbanan inilah yang dilakukan oleh Śrī Rāma sebagai seorang raja, bersama istrinya Dewi Sita sebagai seorang ratu di kerajaan Ayodhya yang rela berpisah demi terciptanya kondisi yang kondusif di dalam masyarakatnya. Dalam cerita Uttarakānda, hal ini terjadi ketika masyarakat di kerajaan Ayodhya merasa resah akan ketidaksucian Dewi Sita. Dengan berat hati, Śrī Rāma akhirnya mengasingkan Dewi Sita istrinya sendiri demi mengkondisikan hal tersebut. Kisah ini bukanlah mencerminkan kejahatan atau tindakan buruk suami yang tega mengusir istrinya, melainkan kewajiban dari seorang raja atau pemimpin yang dalam hal ini Śrī Rāma untuk menciptakan suasana yang damai dalam wilayah kerajaannya meskipun Ia harus menanggung rasa sedih yang sangat besar. Hal yang perlu dipahami dalam hal ini, Śrī Rāma bukanlah hanya sebagai suami, melainkan dilain pihak juga berperan sebagai raja yang melayani masyarakat kerajaan Ayodhya. Sehingga tindakannya bukanlah merupakan suatu tindakan yang jahat. Bahkan untuk mempertegas hal ini, dalam Yajurveda IX. 22 ada sloka yang berbunyi sebagai berikut:

Iyam te rad yantasi yamano dhruvo-asi dharunah, kryai tva ksemaya tva rayyai tva posaya tva.

Terjemahan:

"Wahai pemimpin, itu adalah negara-mu, engkau pengawasnya. Engkau mawas diri, teguh hati dan pendukung warga negara. Kami mendekat padamu demi perkembangan pertanian, kesejahteraan manusia, kemakmuran yang melimpah.” (Dwaja dan Mudana, 2018: 32). 
Jadi sloka tersebut mengandung makna implisit bahwa, jika menginginkan negara yang makmur, seorang pemimpin perlu mendapatkan dukungan dari masyarakatnya. Kemudian untuk mendapatkan dukungan masyarakatnya, seorang pemimpin memang sudah selayaknya selalu mawas diri, dan memiliki hati yang teguh sebagai pendukung warga atau masyarakatnya. Hal inilah yang bisa dijadikan pesan moral dalam kehidupan saat ini, terutama bagi generasi muda yang nantinya sebagai pemimpin-pemimpin bangsa untuk selalu mengutamakan kepentingan umum dibandingkan kepentingan pribadi dengan sikap yang teguh. Sama seperti yang dilakukan oleh Śrī Rāma dalam cerita Uttarakānda.

\subsection{Melaksanakan Kewajiban dengan Keteguhan Hati}

Sudah sepatutnya, terlahir sebagai makhluk paling sempurna, manusia yang memiliki kelebihan berupa Citta (Alam Pikiran) melaksanakan kewajibannya sebagai mana mestinya. Walaupun kewajiban tersebut akan terasa sangat menyakitkan untuk diri sendiri bahkan beresiko. Untuk itulah perlu keteguhan hati, kepercayaan, dan penyerahan diri ketika melakukan kewajiban kepada Tuhan Yang Maha Esa. Hal inilah yang dilaksanakan oleh Laksamana dan Satrughna sebagai adik dari Śr̄̄ Rāma yang merupakan raja di kerajaan Ayodhya. Pertama dari Laksamana sendiri, beliau bersedia menahan rasa sakit ketika melaksanakan kewajiban yang diperintahkan untuknya dalam hal membawa atau menghantarkan Dewi Sita ke dalam hutan untuk menjalani pengasingan. Setelah melaksanakan hal tersebut, dengan segera Laksamana bersujud dihadapan kaki Dewi Sita dan meminta maaf karena ini adalah kewajiban dirinya sebagai adik dan pelayan dari kakaknya yang juga seorang raja. Meskipun kewajiban ini bagiakan halilintar yang menyambar hatinya.

Kemudian yang kedua, dari Satrughna sendiri, beliau dengan perasaan yang teguh bersedia melaksanakan kewajiban yang dilimpahkan untuknya. Bahkan tugas atau kewajiban yang diberikan oleh Śrī Rāma cukup beresiko karena perlu menghadapi seorang Asura sakti bernama Lavana. Namun dengan rasa sujud dan bhaktinya sebagai adik dan pelayan kerajaan, terlebih tugas ini dilaksanakan demi membebaskan para Bhagavan dari teror Asura tersebut, Satrughna sebagai seorang ksatria melaksanakan kewajibannya dengan tulus untuk melindungi penduduk atau warga kerajaan yang tertimpa masalah. Kemudian benar saja, berkat keteguhan hatinya, penyerahan diri yang tulus kepda Hyang Kuasa, serta berkat bantuan dari Bhagavan Cyavana yang memberitahukan seluk beluk kekuatan tombak Lavana, Saturghna berhasil mengalahkan Lavana, dan membebaskan para Bhagavan di tepi sungai Yamuna dari teror Asura Lavana. Jadi dapat diketahui bahwa bagian Uttarakānda memberikan pesan moral bahwasanya setiap manusia berhak dan wajib melaksanakan kewajibannya sebagai mana mestinya untuk pembebasan, hal ini sesuai sloka yang terdapat dalam kitab Manawa Dharmasastra II. 5 (dalam Dwaja dan Mudana, 2018: 33) yang berbunyi sebagai berikut:

\section{Tê̂u samyag vartta màno gacchatya maralokatàm, yathà samkalpitàýúceha sarwan kaman samaúnute}

\section{Terjemahan:}

"Ketahuilah bahwa ia yang selalu melaksanakan kewajiban-kewajiban yang telah diatur dengan cara yang benar, mencapai tingkat kebebasan yang sempurna kelak dan memperoleh semua keinginan yang ia mungkin inginkan."

\subsection{Kebenaran akan Selalu Menang}

Dalam cerita asal-usul para raksasa tak terkecuali Ravana di dalam bagian Uttarakānda, bisa diketahui bahwasanya mereka memiliki kekuatan yang dasyat, bahkan bisa mengacaukan seisi dunia dan menguasai alam para dewa pada awalnya. Namun semua kejahatan mereka pada akhirnya dapat ditaklukan, dan bendera kebenaran kembali dikorbarkan. Dalam hal ini Śrī Rāma sebagai Avatara Dewa Visnu berhasil menepati janjinya kepada Dewa Indra untuk menaklukan para raksasa tak terkecuali Ravana yang menggangu kehidupan dunia. Hal ini juga 
sesuai dengan bunyi sloka Bhagavad Gita IV. 7 dan 8 (dalam Maswinara, 1997: 191) yang berturut-turut dipaparkan sebagai berikut:

Yadà yadà hi dharmasya glànir bhavati bhàrata, abhyutthànam adharmasya tadàtmànam srjàmy aham.

Terjemahan:

"Manakala kebajikan dan kebaikan (dharma) mengalami kemusnahan, dan kejahatan mengalami peningkatan secara merajalela, Wahai putra Bharata (Arjuna), pada saat itulah Aku menjemalkan diri-KU.“

Paritrànàya sàdhànàm vinàsàya ca duskrtàm, dharma-samsthàpanàrthaya sambhavàmi yuge-yuge.

Terjemahan:

"Dalam rangka melindungi orang-orang suci (sadhu) dan baik, untuk memusnahkan orang-orang jahat, dan menegakkan kembali prinsip-prinsip dharma, Aku menjelmakan diri-Ku dari masa ke masa."

Jadi dua buah sloka tersebut meyakinkan seluruh umat manusia, bahwasanya ketika ketidakbenaran merajarela, Tuhan sendirilah yang akan turun kedunia untuk menegakkan kembali prinsip-prinsip kebenaran. Jadi untuk itulah dengan nilai-nilai moralitas, diharapkan manusia senantiasa berperilaku yang mulia demi kesejahteraan hidupnya. Nilai-nilai moralitas tersebut tentu perlu dipetik dari pesan moral dalam cerita Uttarakanda yang telah dipaparkan.

\section{KESIMPULAN}

Rāmāyana perlu dibaca atau dipelajari secara sungguh-sungguh sampai pada bagian akhirnya yaitu Uttarakānda. Hal tersebut dikarenakan, bagian Uttarakānda merupakan resolusi atau tahap koda pada wiracarita Ramāyanna yang berisi penyelesaian akhir dari setiap permasalahan yang ada pada bagian-bagian sebelumnya. Di bagian ini pula terdapat banyak pesan moral mulia yang bisa dijadikan pedoman dan pengajaran untuk menghadapi kehidupan saat ini. Secara garis besar, bagian inti Uttarakānda menceritakan kisah pilu pengasingan Dewi Sita yang tengah hamil ke dalam hutan. Di dalam pengasingannya, Dewi Sita ditemukan dan diasuh oleh mahārşi Vālmīki sampai pada akhirnya melahirkan dua orang putra bernama Kusa dan Lava. Selain cerita inti, terdapat juga cerita sisipan yang berisi tentang; asal-usul para raksasa, keadilan raja Śrī Rāma, dan keberanian pangeran Satrughna dalam menghadapi raksasa Lavana. Dari semua cerita pada bagian Uttarakānda tersebut, dapat ditemukan berbagai pesan moral yang berguna bagi kehidupan, seperti; kesetiaan suami-istri, penghormatan kepada wanita, berkorban untuk kepentingan umum dibandingkan kepentingan pribadi, melaksanakan kewajiban dengan keteguhan hati, serta nilai kebenaran yang akan selalu menang meskipun diakhir. Semua pesan moral dalam cerita Uttarakānda tersebut juga telah memiliki acuan dari ajaran luhur Susila yang bersumber dari sastra suci Veda sebagai kitab suci agama Hindu, sehingga pesan moral tersebut menjadi sesuatu yang valid jika diterapkan sebagai pedoman menjalani kehidupan.

\section{DAFTAR PUSTAKA}

Adiputra, dkk. 2004. Dasar-Dasar Agama Hindu. Surabaya: Depatemen Agama Republik Indonesia.

Budhita S, I Nyoman. 2019. Manusia, Agama, dan Sastra. Yogyakarta: Deepublish Publisher. 
Dwaja, I Gusti Ngurah dan Mudana, I Wayan. 2018. Pendidikan Agama Hindu dan Budi Pekerti untuk Siswa SMA/SMK Kelas XII (Edisi Revisi). Jakarta: Pusat Kurikulum dan Perbukuan, Balitbang, Kemdikbud.

Gata, I Wayan. 2020. Dekontruksi dan Rekontruksi Fenomena 'Nitip Raga' pada Sejumlah Keluarga Hindu di Jawa Timur. Badung: Nilacakra.

Gunarsa, Singgih D. 2017. Perkembangan Psikologi. Jakarta: PT BPK Gunung Mulia.

Mantra, Ida Bagus. 2018. Tata Susila Hindu Dharma. Denpasar: Udayana University Press.

Maswinara, I Wayan. 1997. Bhagavad Gita: Dalam Bahasa Inggris dan Bahasa Indonesia. Surabaya: Paramita.

Oka, Ida Pedanda Gde Nyoman Jelantik. 2009. Sanatana Hindu Dharma. Denpasar: Widya Dharma.

Salim dan Haidir. 2019. Penelitian Pendidikan (Metode, Pendekatan dan Jenis). Jakarta: Prenada Media Group.

Sandika, I Ketut. 2014. Membentuk Siswa Berkarakter Mulia Melalui Pola Pembelajaran Agama Hindu: Telaah Teks Kitab Chandogya Upanisad. Surabaya: Paramita.

Sudharta, Tjok Rai. 2019. Sarasamuccaya Sanskerta dan Bahasa Indonesia (Cetakan Kedua). Denpasar: ESBE Buku.

Sudirga, Ida Bagus, dan Segara, I Nyoman Yoga. 2014. Pendidikan Agama Hindu dan Budi Pekerti untuk Siswa SMA/SMK Kelas X. Jakarta: Pusat Kurikulum dan Perbukuan, Balitbang, Kemdikbud.

Sudirga, Ida Bagus, dan Segara, I Nyoman Yoga. 2014. Pendidikan Agama Hindu dan Budi Pekerti untuk Siswa SMA/SMK Kelas X. Jakarta: Pusat Kurikulum dan Perbukuan, Balitbang, Kemdikbud.

Sugiyono. 2007. Metode Penelitian Pendidikan (Pendekatan Kuantitatif, Kualitatif, dan R\&D). Bandung: Alfabeta.

Suratmini, Ni Wayan. 2016. Buku Penunjang Materi Agama Hindu dan Budi Pekerti untuk Siswa SMA/SMK Kelas X - Semester Ganjil. Denpasar: Tri Agung.

Titib, I Made. 2008. Itihāsa Ramāyāna \& Mahābhārata (Viracarita) Kajian Kritis Sumber Ajaran Hindu. Surabaya: Paramita. 